Shereeza \& Noor Shakirah, , "Views of Selected Malaysian Muslims Academia on Extremism in Islam," Afkār Vol. 19 Special Issue (2017): 147 -

\title{
VIEWS OF SELECTED MALAYSIAN MUSLIM ACADEMIA ON EXTREMISM IN ISLAM AND ITS IMPLICATIONS TO CONTEMPORARY $D A^{`} \boldsymbol{W} A H^{\sharp}$
}

\section{Shereeza Mohamed Saniff *, Noor Shakirah Mat Akhir $^{* *}$}

*School of Social Sciences. Universiti Sains Malaysia. 11800. Pulau Pinang. Malaysia.

${ }^{* *}$ School of Humanities. Universiti Sains Malaysia. 11800. Pulau Pinang. Malaysia.

\section{Email: **shakirah@usm.my}

\begin{abstract}
Khulasah
Islam adalah agama yang menggesa kepada keamanan. Perkataan Islam juga berasal dari akar kata yang membawa maksud selamat dan penyerahan. Walaubagaimanapun perkembangan dan situasi semasa telah memberi gambaran Islam dengan wajah yang sebaliknya. Hari ini, istilah 'ekstremisme' seringkali dikaitkan dengan keganasan dan kekerasan dalam Islam. Situasi ini meningkatkan cabaran kepada Islam hari ini kerana ia menjadi halangan kepada urusan da'wah. Oleh itu objektif artikel ini ialah mengkaji pandangan para ahli akademik terpilih beragama Islam di Malaysia tentang istilah 'ektremisme' dalam Islam. Ini bertujuan untuk menganalisa pemahaman yang berkaitan dengan istilah 'ektremisme' dalam kalangan masyarakat Islam melalui lensa intelektual Islam terpilih di Malaysia. Dua fasa terlibat dalam proses pengumpulan data. Fasa pertama melibatkan kajian empirikal dan fasa kedua melibatkan kajian kepustakaan. Kajian empirikal merupakan maklumat yang dikumpul dari temubual bersemuka separa
\end{abstract}

\# The authors wish to thank the Asian Muslim Action Network (AMAN) based in Bangkok Thailand for the funds given under the Research Fellowship Programme 2009-2010 with the theme "Islam in Southeast Asia: Views from Within". 
struktur secara mendalam yang dijalankan bersama ahli akademik terpilih beragama Islam di Malaysia. Data yang diperolehi dari kajian empirikal telah disusun secara sistematik melalui pendekatan kualitatif. Data yang diperoleh dari kedua-dua fasa juga telah dianalisa menggunakan kaedah analisis tekstual. Artikel ini telah merumuskan dari data yang dikumpul menunjukkan terdapat dua kecenderungan terhadap persepsi 'ektremisme' dalam kalangan ahli akademik beragama Islam terpilih di Malaysia yang mendasari implikasi penting keberkesanan da'wah masakini.

Kata kunci: ektremisme; ahli akademik beragama Islam di Malaysia; da'wah.

Abstract
Islam is a religion that advocates peace. The very
word Islam is derived from its root to bring forth the
meaning of submission. While there is that
acknowledgment that Islam is a religion that
advocates for peace, current depiction of extremism
in Islam, at times suggest the exact opposite. Today,
the term "extremism" is usually associated with
terror and aggression of Islam. This presents itself as
a rising challenge to Islam today as it becomes the
hindering block to contemporary da wah. As such
this article sets out to examine the standpoint from
the perspective of selected Malaysian Muslim
Academia on the term "extremism" in Islam. It
attempts to analyse the misunderstanding that is
prevalent on the term "extremism" within the
Muslim society through the lenses of selected
Malaysian Muslim intellectuals. For the collection
of data, two phases were embarked upon. The first
phase consisted of the empirical research whilst the
second phase involved library research. The
empirical research refers to the information received
through the face-to-face semi-structured in-depth
interviews to selected Malaysian Muslim Academia.
For the empirical part of data collection the data


obtained was systematically arranged through the qualitative approach. The data collected from the first phase (empirical research) and the second phase (library research) were analysed using the textual analysis method. The article has set out that information collected showed that that there exist two inclinations to the perception of "extremism" among the selected Malaysian Muslim Academia which bears grave implications to the efficacy of contemporary $d a^{6} w a h$.

Keywords: extremism; Malaysian Muslim academia; $d a^{6} w a h$.

\section{Introduction}

The belief in religion is a potential that is innately present in human. Religion implies a belief in God, an appreciation of human vicegerency, and a supremacy over the universe. The primary foundation of true religiosity is a healthy moral system, safe from distortions and artificiality. It is a profound thought, a heart full of lively emotions, an intelligent mind, and emotions loaded with genuine feelings. This belief in religion is related to man's internal aspects.

Islam is a religion through which lives change, and by means of which societies transform according to the divine. Thus it is also man's internal aspects that influence his beliefs. From the Islamic perspective, the potential to imān (faith) is in the nature of human. However, man's belief towards something is influenced by his surroundings. It is within such a surrounding that Islam is currently seen as a religion which according to Sanjeev, when based on western interpretation whose premises are formed from a faulty cognition of the nature and guiding principle of Islam itself, is the reason for the rise of violent extremism involving Muslim radicals. ${ }^{1}$

${ }^{1}$ Sanjeev, Kumar H..M, "Responding to Western Critiques of the Muslim World: Deconstructing the Cliché of Islamophobia and the 
As such Islam is often depicted negatively as a growing threat to world peace. Such depiction has obscured the diversity of opinions permeating within Islam and the fact that most Muslims condemn extremism and violence. $^{2}$ Yet extremists exist unfortunately worldwide, whether referring to the religion or secular ideologies. ${ }^{3}$ The term "extremism" which is usually associated with terror and aggression presents itself as a rising challenge to Islam today. It can be regarded as the hindering block to contemporary da'wah.

Thus this paper intends to set out the findings pertaining to the term 'extremism' in Islam from the perspective of selected Malaysian Muslim Academia as they represent the voices of the academics. According to Ozay Mehmet, one of the pertinent roles of the academics is to preach tolerance and understanding especially when writing about Islam. ${ }^{4}$ Thus this paper sets out to identify the concept of extremism in Islam based on the viewpoints of the harbingers of tolerance and understanding - the Malaysian Muslim Academia. Once identified, this paper then sets to analyse the implications within the context of contemporary $d a^{6} w a h$.

As such this article is divided into nine sections. The second section presents the concept of man's existence in

Genealogies of Islamic Extremism," British Journal of Middle Eastern Studies, 579-598. Retrieved from 10.1080/13530194.2015.1037247 on 10 December, 2016.

2 Mohammad Hashim Kamali, "Extremism, Terrorism and Islam: Historical and Contemporary Perspectives," Islam \& Civilisational Renewal, 6(2), 148-165.

3 Abdulrahman Alrassi, "Fighting Against Religious Extremism and Islamophobia: The Pillar for a Sustainable Harmony Between West and Islam," SEA: Practical Application of Science, vol. 2 issue 1(3)/ 2014, 39-47.

4 Ozay Mehmet, "Writing about Islam: The Role of Academics," Humanomics, 10(2), 58-76. Retrieved from http://dx.doi.org/10.1108/eb018750 on 10 December, 2016. 
Islam while the third section is the literature review. The fourth section presents the corresponding research questions to the research objectives and the fifth section is on the research methods used. The sixth section examines the theoretical framework. The seventh section presents the findings and discussions. Section eight offers suggestions on how to counter the prevalence of extremism in Islam. Section nine concludes this paper.

The succeeding sections present the findings and the analysis with some recommendations as to how each and every individual has a part to play in avoiding the usage of the term 'extremism' when referring to Islam and the Muslim society. However before providing the detailed findings, this article in the succeeding section discusses the fundamentals to the understanding of the concept of man's existence in Islam.

\section{Concept of Man's Existence in Islam}

The concept of the existence of man in Islam differs from the others. This is because this concept is mainly rooted to the tools of Islamic epistemology that is the Qur'an and the Sunnah ${ }^{5}$ of Rasulullah SAW. Thus in Islam, Muslims believe that the purpose of man's creation is to submit to Allah S.W.T. It is through this basic understanding of man's relationship to Allah S.W.T that gives rise to the tawhidic concept ${ }^{6}$. It is this concept that

5 "Sunnah" literally means a way, practice, rule of life; and refers to the exemplary conduct or the model behaviour of Rasulullah SAW in what he said, did or approved. Abdul Rahman I. Doi, Shari 'ah: The Islamic Law (Kuala Lumpur: A.S. Noordeen, 1984), 7.

6 This concept of tawhid (for the purpose of this article the terminology "tawhidic" will be used throughout) refers to the concept of Tawhid which entails Muslims to obey Allah S.W.T., acknowledge that Allah S.W.T. is the only one worthy of worship. It also entails Muslims to obey Allah S.W.T. out of fear and love and hence work hard to avoid displeasing Allah. It is the centre from which the rest of Islam radiates. For further reading on this refer to Mohd. Sulaiman Haji Yasin, Pengantar Aqidah (Kuala Lumpur: Dewan Bahasa dan Pustaka, 1984). 
governs the linear relationship of man and his Creator, Allah S.W.T.

In addition to this certainty pertaining to the purpose of the existence of man, Muslims also believe that in fulfilling their duties as a servant of Allah S.W.T, man needs to fulfil his functions as a khalifah ${ }^{7}$ of Allah S.W.T. Man as khalifah of Allah S.W.T. on earth must be treated as end in himself and never merely as a means since he is the cream of creation and hence the central theme of the Quran ${ }^{8}$. Thus this khalifah concept governs man's horizontal relationship with one another and with other creatures in this world. This means that man is although recognized in Islam, as a social being and part of a bigger scheme of things called the society, he is nonetheless at all times to be mindful of Allah. His tașawwur is at all times moulded by his deep conviction to his tawhidic faith.

With his deep conviction to the tawhidic faith and his fundamental understanding of his role in a bigger society a Muslim understands and accepts the laws of Islam which are firmly based on the shari' $a h .{ }^{9}$ The shari 'ah helps to regulate man's linear relationship with his Creator and his horizontal relationship (that of man

7 "Khalifah" refers to the trustee, the moral agent or the vicegerent. It is a pervasive Qur'anic concept called khiläfah that can be translated as trusteeship, moral agency or vicegerency. This core Qur'anic concept provides the spiritual basis for understanding ethical action in Islam. Harun Din et. al., Manusia dan Islam, Jilid 3 (Kuala Lumpur: Dewan Bahasa dan Pustaka, 1993), 17-24.

8 Abdul Rahman, Shari 'ah, 8.

9 "Shari "ah" is an Arabic word which means the Path to be followed. It is not only the path leading to Allah S.W.T. but also the path shown by Allah S.W.T., through Prophet Muhammad SAW. The term also refers to Islamic legal system whereby the field of Islamic jurisprudence ( $u s \underline{u} l$ al-fiqh) is part of the whole system in deriving legal injunctions in post revelation era which jurists agree to be the secondary sources of shari 'ah known as al-ijm' (consensus), alqiyās (analogical deductions), and al-ijtihād. Abdul Rahman, Shari 'ah, 64. 
with man and other creatures). In regulating his horizontal relationship, the shari'ah acknowledges the existence of man as a social being and thus aims to look after the interests of the people as a whole. Islam is a religion of justice and thus enjoins Muslims to uphold justice. In ensuring justice can be maintained shari'ah places priority to human welfare over human liberty ${ }^{10}$. As society nations change with the progress of time, so too are the nature of challenges, issues and problems faced by the society.

Since Islam advocates justice, a Muslim who follows and holdfasts to this tawhidic concept understands that the absolute law-creating prerogative rests with Allah S.W.T. whilst man only enjoys a derivative rule-making power. He understands that sovereignty belongs to Allah S.W.T alone. Thus he understands that the sanctions and limits placed in shari' 'ah such as the hudīd laws are imposed to curtail man's nafs (ambitions and desires) ${ }^{11}$. In addition boundaries in the form of halāl (lawful) and harām (unlawful) have also been set to ensure that peace and respect are to be maintained at all times whilst governing the horizontal relationship of $\operatorname{man}^{12}$. If man transgresses any of these limits he is committing a wrong or a crime. In referring to transgression, a number of verses in the Qurān remind believers such as in sūrah Hüd, 11:112 which bears the following interpretation: -

"So stand (ask Allāh to make) you (Muhammad SAW) firm and straight (on the religion of Islamic Monotheism) as you are

\footnotetext{
${ }^{10}$ Ibid., 6,9.

${ }^{11}$ Ibid., 5.

12 Muhammad Syukri Salleh, 7 Prinsip Pembangunan Berteraskan Islam (Kuala Lumpur: Zebra Editions Sdn. Bhd. and Pulau Pinang: Projek Pengurusan Pembangunan Islam, Pusat Pengajian Sains Kemasyarakatan, Universiti Sains Malaysia, 2003),18.
} 
commanded and those (your companions) who turn in repentance (unto Allāh) with you, and transgress not (Allāh's legal limits). Verily, He is All-Seer of what you do".

With this tawhidic concept truly entrenched into a man's tasawwur there lies within him a true and deep conviction that Allah S.W.T is the ultimate Lawgiver. Thus issues and problems permeating on the idea and concept of "extremism" have no basis to arise. This is very much in line with the injunctions of the Qur'ān in sürah al-Baqarah, 2: 143 which reminds Muslims to always take the balanced approach which bears the following interpretation:-

"Thus We have made you [true Muslims real believers of Islāmic Monotheism, true followers of Prophet Muhammad SAW and his Sunnah (legal ways)], a (just) (and the best) nation, that you be witnesses over mankind and the Messenger (Muhammad SAW) be a witness over you".

The above discussion has thus far presented the ideal reality of the Islamic society, a society that upholds the shari' 'ah. A society that is truly being embedded by the tawhidic concept upholds peace and respect to all of Allāh S.W.T. creatures being aware at all times of his subservience to the Omnipotence, Allāh S.W.T. A society that understands that although the issues and challenges faced by the Muslims are countless and undaunting yet with full adherence to the tawhidic concept which mould the Islamic society's tașawwur, the Islamic society through the adherence of the shari' $a h$ knows that the society is able to flourish as the Islamic society constantly strives to achieve the ultimate end - to be in receipt of Allah's pleasures (mardàt Allāh).

Such is the Islamic society yet the advent of crisis and dilemma affecting the Muslims which has led to the 
usage of the term 'Islamic extremism' is a conflicting scenario between what is stipulated in Islam being a religion which shows the way of life and that which is faced by the Muslim society of today. Thus this article intends to highlight the central focus on whether there is a justification for referring to the term 'Islamic extremism'.

\section{Literature Review}

This section presents the current stand on the understanding of extremism in Islam. From the reviews of literatures, works discussing and examining extremism in Islam, can be categorized into two main aspects. The first aspect relates to works that seek to understand extremism in Islam from within Islam itself. The second aspect refers to writings that view the notion of extremism in Islam from an outsider's perspective.

The first of these works examined are from writers which viewed extremism in Islam introspectively. Their works are based on the Muslim society from the insider's point of view which look at the term 'extremism' based on Islamic tasawwur and had referred to the tools of Islamic epistemology, that is, al-Qur'an and Sunnah of Rasulullah SAW. In other words, these writers provide a neutral discussion on the topic of Islam and extremism or uphold the sanctity and sacredness of Islam as a religion that promulgates the tawhidic concept.

It was noted that these writers do not refer nor use the term 'Islamic extremism' in their works. In discussing extremism from the perspective of the religion of Islam, these writers made use of terms such as 'extremism in religion' or Arabic phrases that are referred to by the religious texts.

As an example of such works is a book entitled Pengajian Islam (Islamic Studies) written by Ezad Azraai Jamsari, Roziah Sidek, Nasarudin Yunos and Zulkarnain Mohamed (2004). A chapter in this book is devoted to 
discussing the term 'Ektrismisme Agama' (or Religious Extremism) by stating that the historical background of the existence culminated as a product of the Western intellectual thoughts which in turn is used as a 'label'. This label is linked more to the Muslims as compared to the non-Muslims and has interest on the Western economies that is regarded as the proponents of truth and justice.

Besides the label of 'extremism' this book also discussed on the other terms used such as 'fundamentalism' and 'terrorism' which have been misused and misinterpreted with other sacred concepts in Islam such as holding steadfastly to Islam and to strive for Islam. This chapter rather dwells into the clash of civilization of Islam and the West and the resultant divide between these two civilizations.

Then there is the collection of articles written by well renowned scholars from the Middle East and translated by Ismail Mohd Hassan (1984) that examines the opinions and views on the issue of extremism in religion. The articles mostly discussed about the historical background to the existence of 'extremism in Islam' as well extremism in religion of other great religions in this world such as Christianity and Judaism.

There is also a translated work by Abu Az-Zubayr Harrison on an excerpt of a book entitled al-Ghuluww originally written by 'Ali ibn Yahya al-Haddadi (2009) that devoted a chapter of the said work on 'The Forbiddance and Danger of Extremism'. This work discussed a number of Quranic verses and the sayings of the Prophet which commanded adherence to a middle path (wasata) and forbiddance of extremism. This work highlighted specifically the Quranic verses and the 
equivalent terms referred to in the religious texts ${ }^{13}$ which are synonymous to extremism.

The work of Asma Barlas entitled Jihad, Holy War, and Terrorism: The Politics of Conflation and Denial discussed her concerns on 'interpretive extremism' as it was very much dependent on who was defining it. She took the contradiction in perception between terrorism and freedom struggles as an example of such interpretation. It also depended very much on how Muslims themselves can contest it. She advocated two points on how these challenges on interpreting extremism can be dealt with. Firstly, that in reading and interpreting the Quran one needs to have the understanding of the external factors in shaping the politics of the Muslim states. Secondly that Muslims are free to reject oppressive readings of the Quran. This is a result she argued, "of the product of both extremist thinking and the unwillingness of moderate Muslims to challenge it".

In terms of the works that examines extremism in Islam from the second aspect, most of the literatures reviewed of works written from outside of the Islamic tasawwur were those written post 2001. They are referred to as works from 'outside' as their thoughts and discussions directly refer and made use of the term 'Islamic extremism'.

In addition these works, in referring to 'Islamic extremism' does bring the notion of the religion of Islam in an unconstructive style which is antagonistic to the Islamic tasawwur that is firmly based on the tawhidic concept. In other words works that put Islam in a bad light. These works thus view Islam as a religion that advocates violence and aggression.

13 "Religious texts" in this report refers collectively to the primary tools of Islamic epistemology that are al-Qur'an and the Sunnah of Rasulullah SAW. 
In John Francis Murphy's (2002) Sword of Islam: Muslim Extremism from the Arab Conquest to the Attack on America was an attempt to explain and make a distinction between Muslims and Islamic extremism. However the writer had nonetheless mixed up the elements of Islam as a religion and Muslims to that of Islamic extremism and depicted that extremism and violence are constant characteristics of Islam.

Another work of contemporary critics of Islam is the works of author such as Robert Spencer. In one of Spencer's (2006) controversial writing, The Truth about Muhammad: Founder of the World's Most Intolerable Religion that is criticized as showing "entrenched hostility towards Islam" he attributed the violence and aggression that Muslims are prone to the words and deeds of Rasulullah SAW and called for the need for Western governments to limit the influence of moderate Muslims by calling them "to renounce these elements of Islam." Although he relied on what he deemed as "authentic sources" in painting the role and tasks of Prophet Muhammad SAW from what he perceived as "truthful" his work has been widely criticized to be biased as he was said to have omitted texts from passages he quoted and that he had downplayed the passages from the Qur'an urging peace and goodwill.

In a report statement by Robin Niblett (2006) entitled Islamic Extremism in Europe, the report made wanton use of the term Islamic extremism and cited mainly economic disparity as the root of the problem "as the awakening fear in Europe" which in turn had caused the growing sense of frustration and alienation of the second and third generation Muslim immigrants to Europe.

From the above examination, there are two inclinations in viewing the concept of extremism in Islam. The first group attributes the existence of extremism within Islam as a result of mainly two factors. 
The first factor is with regards to the subjective interpretation referring to the nuance of the term being dependant on whose point of view is one coming from. The second factor is attributed to historical aspects. However there is a congruence of thoughts that extremism in Islam can be and should be avoided by returning to al-Qur'an and Sunnah of Rasulullah SAW and guided by the principles (such as on wasata - taking a middle course) contained within these two primary sources of knowledge in Islam. When the conceptualization is based on the primary sources of Islam, then a correct tasawwur can be held onto. With the right tasawwur one will be steered away from extremists' tendencies.

On a contrasting note, the second group tends to use the term 'Islamic extremism' and interpret the advent of such existence based mainly on external factors or selective interpretation of their understanding of the primary sources of Islam whilst economic disparity has also been cited as a main reason to the rise of extremism within Muslims. To this group, religion is the hindrance to Muslims' progress and prosperity which has led to the root cause of their extremists' tendencies.

Since there are polarities in the views of extremism in Islam, it brings this paper to question as to whether should there or should there not be the notion of Islamic extremism especially in the light of contemporary $d a^{6}$ wah movement? This brings to the succeeding subsection in examining the issue at hand simultaneously answering the pertinent question.

\section{Is There Such a Thing as Islamic Extremism in the Light of Contemporary $\mathrm{Da}^{6}$ wah?}

As with the passing of time, the issues and problems faced by the society are myriad indeed. Islam and the Muslims society are not freed either of such challenges. However, with the passing of time and the advent of 
technological advances and globalization, a new threat is permeating the Muslim world that is jeopardizing the existence of Islam in this contemporary world. Post September 11, 2001 has put terrorism on the American and international agenda and became the topic of many writings, researches and conferences ${ }^{14}$.

It has spurned the usage of the term 'Islamic extremism', which of late is equated with terrorism, loosely used to depict the sense of aggression and terrifying an opponent ${ }^{15}$ and has the inclination to be equated with violent Islamic activists though many mainstream Muslims would say they are not Islamic at all. Such negative depiction of Islam permeates the thinking of the general masses provides a number of implications to contemporary $d a^{6} w a h$. This brings to the objective of the research that is to measure the extent of conformity in the Malaysian Muslim academia to the term that is loosely used as 'Islamic extremism'. This brings to the question as to the perception of the Muslim academia to the term 'Islamic extremism' and whether the Muslim academia perceived the term to be similar to terrorism. Does 'Islamic extremism' necessarily give rise to terrorism?

Thus to bring the study to focus, this pilot study is to be conducted to selected Malaysian Muslims academia at the four Institutions of Higher Learning in Malaysia. These institutions are purposively selected based on the criterion that the institution is built on Islam as the primary seat of knowledge or that has their own faculty

${ }^{14}$ Ruhanas Harun, "On Youth and Terror," accessed December 22, 2009 ,

http://www.ssig.gov.my/ssig/kcent/material/PAPER_CONFEREN

CE_ON_YOUTH_AND-TERROR20\%ruhanas.pdf.

15 Al-Tayib Zain al-Abdin, "The Intellectual Roots of Terrorism" in Al-Ghuluw, trans. Abu Az-Zubayr Harrison, 15-21, accessed July 30, 2010, http://www.answering-extremism.com/transpub/ae_aah_2.pdf. 
of Islamic Studies. It is therefore the aim of the study to determine the trends in perception to the term 'Islamic extremism' by these selected Malaysian Muslims intellectuals. With their perception determined, a more focused approach could be undertaken to deal with extremism in Islam in the Malaysian context. Through this focused approach, the concept and underpinnings related to the term 'Islamic extremism' would provide a more realistic and practical resolution. It will thus allow for a better understanding in tackling the issues related to violence and aggression which are plaguing the Muslim society.

\section{A Focus Approach on 'Islamic Extremism'}

The discussion above has shown that there is a duality of existence between what is commanded in Islam, a conscious adherence to the tawhidic faith and the state of affairs beleaguering the Muslim society of today. Furthermore, the dynamism of the term 'extremism' on its own and now coupled with the term 'Islamic' has made it more pressing to determine whether a united stand especially among the Muslim intellectuals, (for the purpose of this article selected Malaysians academician being the focused group), whether the usage and reference of the term 'Islamic extremism' can justifiably be referred to.

In addition, the negative connotation that the term 'Islamic extremism' carries especially post September 9/11 provide a strong need to dispel the fabrication towards the negative nuance that the term 'Islamic extremism' carries. Is there actually such a term as 'Islamic extremism' as often depicted by the nonMuslims and even the Muslims themselves? Thus to ensure that the research embarked for this article remained focused and concluded within the timeframe and budget allocated, two research questions had been 
identified. This was achieved by focusing the research questions to the following:-

i. How do the Muslims intellectuals in the Institutions of Higher Learning in Malaysia perceive about the term 'Islamic extremism'?

ii. What characteristics are regarded as 'extremists' in Islam?

These research questions were the guiding parameter that led to the next phase of the research. The next phase refers to the methods employed in obtaining the data required and the analysis thereof which is presented in detail in the succeeding section of this article.

\section{The Research Methods Used}

As mentioned in the preceding section, this section of the article is devoted to outlining the details of the methodology used to meet the objective which were divided into two main stages, Data Collection Stage and Analysis of Data Stage. In collecting the data, the research has divided the Data Collection Stage into two phases: -

i. Empirical Research Phase; and

ii. Library Research Phase.

\section{a. Data Collection}

For the collection of data, two phases were embarked upon. The first phase consisted of the empirical research whilst the second phase involved library research.

\section{i. First Phase: Empirical Research}

The empirical research refers to the information received through the face-to-face semi-structured in-depth interviews to selected Malaysian Muslim Academia. The primary data obtained at this phase allowed for a more focused library research in the second phase. The data received from this second phase is then used to provide the basis and background for the analysis to be carried 
out which was to meet the theoretical part of the research. Specifically, the theoretical part of the research was carried out to examine the existing literature on the term 'Islamic extremism'. All these were done with the two research questions identified as the guidelines so that the objective of this research was at all times kept in view.

\section{The Face-to-face Semi-structured Interviews}

The selected Malaysian Muslim academia was chosen as the focus group of the research because the term 'extremism' is not a political issue in isolation but has also sparked debate in the academia world. It is envisaged that the standpoint of the Malaysian Muslim academia on the issue on "extremism' can lead to a focused stance in formulating further discussion on this issue.

For the purpose of this research, semi-structured indepth interviews were carried out to the selected Malaysian Muslim academia from the specified four Institutes of Higher Learning in Malaysia. Three Malaysian Muslim academicians were randomly selected from each of these institutions. Thus twelve respondents were interviewed.

The in-depth interview method is considered as one of the important sources to obtain information in a research case study ${ }^{16}$. This method which is used in this research dictated that researcher and respondents directly and actively interact ${ }^{17}$. The questions for the semistructured interview had been predetermined which ensured that the researcher could examine the research issues from the perspective of the subject matter of the study.

\footnotetext{
${ }^{16}$ Robert K. Yin, Case Study Research Design and Methods (London: Sage Publications, 1984), 82.

17 Mohd. Majid Konting, Kaedah Penyelidikan Pendidikan (Kuala Lumpur: Dewan Bahasa dan Pustaka, 1998), 237.
} 
The semi-structured interview allowed the researcher to re-arrange the questions during the interview sessions. It provided flexibility to the structure of the questions and the opportunity for the researcher to add or eliminate questions based on necessity ${ }^{18}$. This method also allowed the receipt of detailed information through the open-ended questions posed.

\section{Profile of the Respondents}

For the purpose of this pilot study twelve respondents had been interviewed and are marked as R1 to R12. The profile of these respondents has been summarily presented in table 1.1 below:-

Table 1.1: The Profile of Respondents

\begin{tabular}{|c|c|c|c|c|c|}
\hline Respondent & Gender & Age & $\begin{array}{c}\text { Highest } \\
\text { Qualification }\end{array}$ & Specialization & $\begin{array}{c}\text { Years of } \\
\text { Experience }\end{array}$ \\
\hline R1 & Male & 53 & $\mathrm{PhD}$ & $\begin{array}{c}\text { Aqidah \& Islamic } \\
\text { Thought }\end{array}$ & 24 \\
\hline R2 & Male & 47 & $\mathrm{PhD}$ & $\begin{array}{c}\text { Aqidah \& Islamic } \\
\text { Thought }\end{array}$ & 20 \\
\hline R3 & Female & 40 & $\mathrm{PhD}$ & $\begin{array}{l}\mathrm{Da}^{a} \text { wah \& } \\
\text { Counselling }\end{array}$ & 15 \\
\hline R4 & Female & 40 & $\mathrm{PhD}$ & $\begin{array}{l}\text { Psychology of } \\
\text { Da'wah \& } \\
\text { Adolescents }\end{array}$ & 15 \\
\hline R5 & Male & $\begin{array}{c}\text { Un- } \\
\text { disclosed }\end{array}$ & $\mathrm{PhD}$ & Islamic Thought & 35 \\
\hline R6 & Female & 53 & $\mathrm{PhD}$ & Islamic Thought & 22 \\
\hline R7 & Male & 51 & $\mathrm{PhD}$ & $\begin{array}{l}\text { Da'wah \& } \\
\text { Leadership }\end{array}$ & 27 \\
\hline R8 & Male & 39 & Master & Fiqh \& Usul Fiqh & 9 \\
\hline R9 & Male & 43 & $\mathrm{PhD}$ & $\begin{array}{c}\text { Islamic Political } \\
\text { Science }\end{array}$ & 19 \\
\hline R10 & Male & 62 & $\mathrm{PhD}$ & $\begin{array}{l}\text { Usuluddin \& } \\
\text { Comparative } \\
\text { Religion }\end{array}$ & 23 \\
\hline R11 & Male & 32 & $\mathrm{PhD}$ & Maqasid Syariah & 4 \\
\hline R12 & Male & 43 & $\mathrm{PhD}$ & $\begin{array}{c}\mathrm{Da}^{c} \text { wah \& Human } \\
\text { Development }\end{array}$ & 4 \\
\hline
\end{tabular}

18 Chua Yan Piaw, Kaedah dan Statistik Penyelidikan: Kaedah Penyelidikan Buku 1 (Kuala Lumpur: Mc Graw Hill, 2006), $117-$ 118. 
The allocated time for each of the interview session was one hour. However the longest interview lasted for almost three hours (R5) whilst the shortest was a mere half an hour (R4). The interview sessions of the rest of the other respondents were kept at an hour. All respondents were primarily asked based on the guidance of the six questions which researcher had predetermined prior to the interview sessions.

\section{Location and Extent}

The four Institutions of Higher Learning were selected based on the criterion that either the institution is built on Islam as the primary seat of knowledge or that the institution has its own faculty of Islamic Studies. Three of the four Institutions of Higher Learning were located within the Klang Valley of Malaysia whilst one Institution of Higher Learning was located on the outskirts of the Klang Valley. Three respondents were randomly selected from each of these institutions.

For the Empirical Research, the researcher conducted face to face semi-structured in-depth interviews to twelve respondents from the four selected institutions of Higher Learning in Malaysia. Prior to conducting the semi-structured in-depth interviews, several e-mails and phone calls were made to the respondents to confirm the date and venue of the intended interview session. The interviews were primarily conducted by the researcher using the English Language. However, the respondents were free to provide their responses in the Malay Language.

\section{ii. Second Phase: Library Research}

This phase was conducted throughout the research. It consisted mainly of two parts. The first part was to complement the empirical research whilst the second part complemented the theoretical part of the research which was also used as a template to carry out the basis for analysis. This phase was conducted with the focus to 
reviewing the existing literature on the central theme of this research and the gap in research on this matter. It also provided the template to be used as the basis for analysis for the Analysis of Data category of this research.

The first part complements the empirical part of the research and is dedicated to identifying the status of this research undertaken and to determine the academic gap on the central theme of this research. This includes any reference made to the main sources of knowledge in Islam that is al-Qur'an, Ahādith, ijmā' al-'ulamā' and qiy $\bar{a} s^{19}$. They are the basis of the execution of this research.

The second part of the library research was to meet the theoretical part of the research. Specifically the theoretical part of the research was is to examine the characteristics that are regarded as extremes in Islam based on the fundamentals to the development of human thoughts from the Islamic perspective. However for the purpose of this research the reference was limited to those containing the information that allowed an understanding of the principles, concepts and objectives of extremism in Islam.

This second phase also included any documents, texts and materials on extremism in Islam. This ensured that the theoretical part of the research could be carried out because the evaluation on the development of human thought from the Islamic perspective would be used for the analytical part. Thus the theoretical part of the research required that the data collected be analysed. The next section details the method employed in analysing

19 'Ijmā 'al-'ulamā' refers to consensus of opinion of 'Ulamā' whilst qiyas refers to analogical deductions. However both provide detailed understanding derived from al-Qur'an and Ahädith. 'Ijmā 'al- 'ulamō' and qiyās are considered the third source of knowledge after al-Qur'an and Ahādith. Abdul Rahman, Shari' 'ah, 6. 
both the data collected from the empirical research phase as well as the library research phase above.

\section{b. Analysis of Data}

For the empirical part of data collection, the data obtained was systematically arranged through the qualitative approach. This means that the analysis of data involved the analysis of any phrase, sentences used thematically and holistically to identify the understanding to the term extremism. For that purpose the categorization techniques were employed.

The data collected from the first phase (empirical research) and the second phase (library research) as set out in the preceding section were analysed using the textual analysis method. It is a method used by researches to describe and interpret characteristics of a recorded or visual message ${ }^{20}$. Textual analysis describes the content, structure and functions of messages contained in texts as its purpose is to ascertain the meaning intended by the producer of the text. In this research, the responses received from the semi-structured in-depth interview which relate to the term "Islamic extremism" provided the data to be analysed textually for the purpose of the research.

The textual analysis approach was also used for the theoretical part of the research. This is because the method allowed the examination and explanation in a systematic manner the meaning or implicit contents of the documents that are being studied. This approach involves the assessment and analysis of the existence of the meaning and concept in the texts as well as the

20 Norman K. Denzin and Yvonna S. Lincoln, Handbook of Qualitative Research (Thousand Oaks: Sage Publications, 1994), 225 . 
relationship of words and phrases in the texts with the said concepts ${ }^{21}$.

The results obtained, analysing the primary data obtained through the empirical research pertaining to the views and mews of the selected Malaysian Muslim academia on 'Islamic extremism' was achieved through this means. A summary of the above method adopted in carrying out the research is best presented in Figure 1.1 below:-

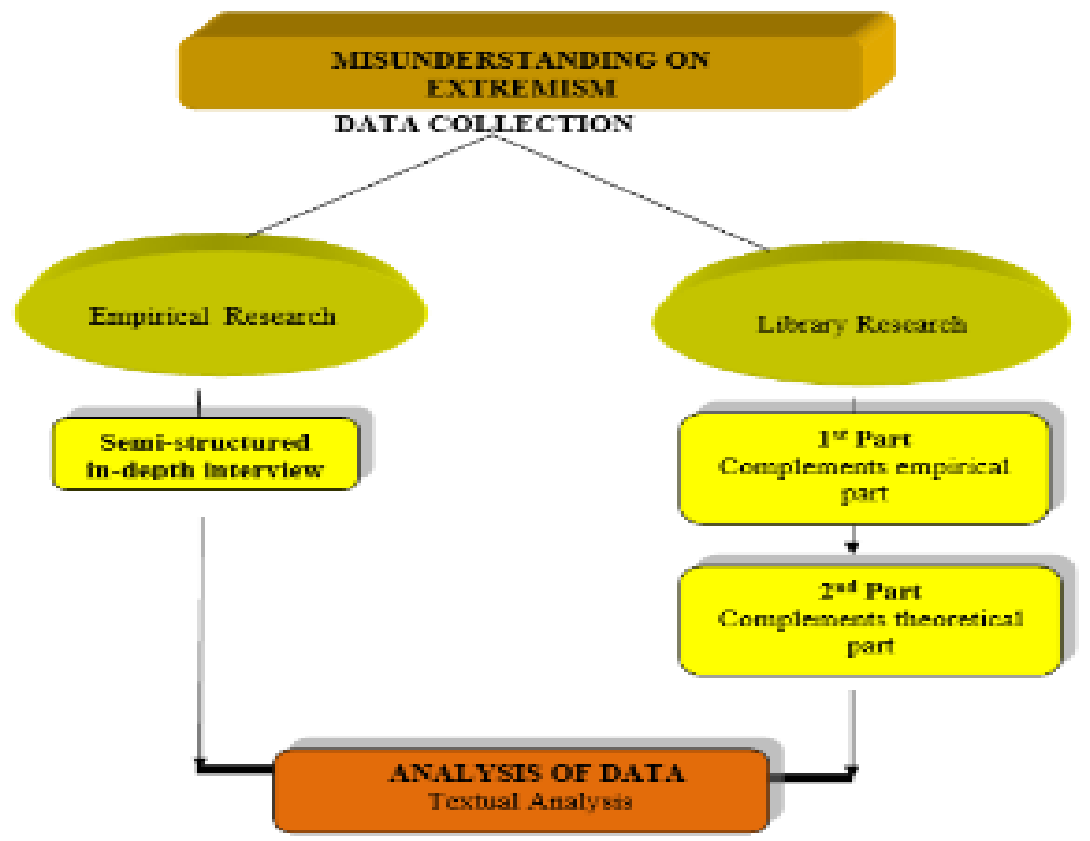

Figure 1.1: Outline of Research Method Employed in the Research

The outline of the research method enumerated above has helped to ensure that the research remained focus throughout. With a focused stand, it allowed for the

21 Rohana Yusof, Penyelidikan Sains Sosial (Pahang: PTS Publications \& Distributors, 2003), 35. 
analytical part of the research be carried out based on the findings collected during the empirical research.

\section{Research Findings and Analysis on 'Islamic Extremism'}

This article has thus far set out the research objectives and the methods employed to achieve the objectives of the research embarked. It has also stated briefly current literatures pertaining to the subject matter in this research and also laid out the theoretical framework used to support the analysis of the findings in this research. This section of the article will therefore present the findings based on the empirical phase of the research and the analysis thereof. The findings are presented based on the general guideline of the questions posed to the respondents which can be classified into three main headings.

\section{a. Definition and Characteristics of 'Islamic Extremism'}

In general all respondents unanimously disagreed with the term 'Islamic extremism' stating that it was a nonsensical and inaccurate term. They provided the alternative term that should be used in its place. A summary of the answers to the question on the respondents' understanding/definition of the term 'Islamic extremism' and in their view an alternative term to be used to negate 'Islamic extremism' is provided in Table 1.2 below: 
Table 1.2 Summary of Respondents' Responses on "Islamic Extremism" and Alternative Term

\begin{tabular}{|c|c|c|c|}
\hline $\begin{array}{c}\text { Responde } \\
\text {-nt }\end{array}$ & Response & Reason & $\begin{array}{l}\text { Alternative } \\
\text { Term }\end{array}$ \\
\hline R1 & No & $\begin{array}{l}\text { 1)In the context of } \\
\text { Mu'tazilah } \\
\text { 2) Use of brute force } \\
\text { 3) Support of ideology that } \\
\text { promotes force which } \\
\text { opposed al-Qur'an and } \\
\text { Sunnah }\end{array}$ & $\begin{array}{l}\text { - "Fahaman } \\
\text { pelampau" } \\
\text { (Extreme } \\
\text { teachings) }\end{array}$ \\
\hline $\mathrm{R} 2$ & No & $\begin{array}{l}\text { Difference of interpretation } \\
\text { which is caused by the root } \\
\text { of the problem that is } \\
\text { political and leadership }\end{array}$ & $\begin{array}{l}\text { - } \quad \text { Muslims } \\
\text { extremism }\end{array}$ \\
\hline R3 & No & $\begin{array}{l}\text { Only extreme actions as } \\
\text { self-defense }\end{array}$ & - al-ghuluwwun \\
\hline $\mathrm{R} 4$ & No & $\begin{array}{l}\text { Extreme with regards to } \\
\text { Islamic teachings }\end{array}$ & - ta'așșub \\
\hline R5 & No & $\begin{array}{l}\text { 1)Muslims who transgress } \\
\text { the limits } \\
\text { 2)Beyond what is necessary }\end{array}$ & $\begin{array}{l}\text { - Religious } \\
\text { extremism in } \\
\text { Islam } \\
\text { - al-ghuluwwun } \\
\text { fí al-dinn } \\
\text { - al-tatarruf } \\
\text { - tashaddid } \\
\text { (making } \\
\text { things narrow) }\end{array}$ \\
\hline R6 & No & $\begin{array}{l}\text { 1)"Islamic" infers optimum, } \\
\text { balanced, moderate } \\
\text { 2) Term is paradoxical and } \\
\text { judgmental } \\
\text { 3) Not justified and not } \\
\text { logical }\end{array}$ & $\begin{array}{l}\text { - } \text { militant } \\
\text { Muslims } \\
\text { - radical } \\
\text { Muslims }\end{array}$ \\
\hline R7 & No & $\begin{array}{l}\text { 1)Term is promoted by } \\
\text { enemies of Islam and the } \\
\text { media; } \\
\text { 2) Globalization with } \\
\text { English as the common }\end{array}$ & - al-ghuluwwun \\
\hline
\end{tabular}


Shereeza \& Noor Shakirah, , "Views of Selected Malaysian Muslims

Academia on Extremism in Islam," Afkār Vol. 19 Special Issue (2017): 147-

\begin{tabular}{|c|c|c|c|}
\hline & & language & \\
\hline $\mathrm{R} 8$ & No & $\begin{array}{l}\text { 1) Not based on Islamic } \\
\text { religious texts } \\
\text { 2) Popularized by the non- } \\
\text { muslims }\end{array}$ & $\begin{array}{l}\text {-"pelampau } \\
\text { agama" } \\
\text { (religious } \\
\text { extremists) }\end{array}$ \\
\hline R9 & No & $\begin{array}{l}\text { 1)There is no extreme } \\
\text { teachings in Islam }\end{array}$ & $\begin{array}{l}\text {-Islamic } \\
\text { Awareness/Revi } \\
\text { valism } \\
\text { - Iṣlāh/Tajdìd }\end{array}$ \\
\hline R10 & No & $\begin{array}{l}\text { 1) Only a certain group of } \\
\text { people can practice } \\
\text { 2) Not universal thus cannot } \\
\text { be categorized as Islamic } \\
\text { way at all }\end{array}$ & \\
\hline R11 & No & $\begin{array}{l}\text { 1)Merely an assumption } \\
\text { which needs to be } \\
\text { researched } \\
\text { 2)Lack of exemplified } \\
\text { character of Muslims } \\
\text { today }\end{array}$ & $\begin{array}{l}\text { - al-tațarruf } \\
\text { - ta'așșub }\end{array}$ \\
\hline R12 & No & $\begin{array}{l}\text { 1) Defensive rather than } \\
\text { oppressive } \\
\text { 2) Exist due to } \\
\text { misunderstanding in the } \\
\text { context of religion }\end{array}$ & $\begin{array}{l}\text { - religious } \\
\text { extremists } \\
\text { - "golongan } \\
\text { salah faham" } \\
\text { (those who } \\
\text { misunderstoo } \\
\text { d) }\end{array}$ \\
\hline
\end{tabular}

All respondents do not agree to the term as meant by the non-Muslims. It is misnomer and to use the term 'Islamic extremism' is "nonsensical". This is because when something is said to be Islamic it could not be extreme. It is wasața (correct and balanced). If it is extreme then it is not Islamic.

In referring to the existence of Muslim extremists, they agreed that extremist traits could transpire. The 
respondents stated that there is the equivalent Arabic term such as al-ghuluwwun, al-tațarruf and ta'așub to indicate the acknowledgement of such tendencies within the Muslim community. From these words concepts such as al-ghuluwwun fí al-din (extreme in religion) are derived therefrom.

All respondents although do not agree to the usage of the term 'Islamic extremism' however agreed that there is such an element of 'extremism' within the Muslim community. R2 and R5 however elaborated further by stating that extremism is found in all religions and is not confined and restricted to the religion of Islam.

All respondents iterated that their definition and understanding of the term differs to that as used and understood by the non-Muslims. According to them the term as used by the non-Muslims is usually associated with the element of brutality and violence. R9, R10, R11 and R12 emphasised that these Muslims who are religiously extreme only exist as a small group and are a minority in the community. They do not represent the vast majority of the Muslims worldwide.

Although the respondents agreed to the use of the term such as Muslim extremists or extremism in religion (as mentioned above) however the respondents do not agree to the sense as depicted by the non-Muslims when using the term. All respondents agreed that there exist extreme elements among Muslims and the Arabic terms such as al-ghuluwwun, al-tațarruf $f^{2}$ and ta'așsub ${ }^{23}$ are

22 The Arabic terms al-ghuluwwun and al-tatarruf have its epistemological basis in the Qur'an and Hādith. For example the term al-ghuluwwun (or its Arabic derivatives) can be found in Sürah al-Nisā', 4: 171 and Sürah al-Ma' idah, 5:77 whilst the term al-tatarruf (or its Arabic derivatives) can be found in Sūrah Hūd, 11:112.

23 The term ta'așsub has been defined as the inability to receive the truth because it is not suitable with one's stance [H. Mahmud Junus, Kamus Arab-Indonesia (Jakarta: Yayasan Penyelenggara Penterjemah/Pentafsiran Al-Quran, 1972), 268]. The Arabic term 
already in the Islamic vocabulary to depict and describe succinctly these extremists.

In supporting their stand that extremism do permeate within the Muslim community R3, R4, R5, R7 and R11 illustrated their line of reasoning by mentioning that extremism do occur in the spiritual sense such as while an individual performs the acts of worship ( $i b \bar{a} d a h$ ) to Allāh SWT. R5 added that in one's performance of the rituals of worship there has to be a level of "fanaticism" in bringing up one's consciousness as a servant and khaliffah of Allāh SWT. Fanaticism is justified when an individual Muslim has a high level of conviction and love for Islam. However R5 went on to remind that this fanaticism is applicable personally and cannot be imposed on the Muslims at large. When imposed on others it can thus be deemed as extreme.

These respondents mentioned that the proposition to be moderate and not extreme is enjoined by Islam through the naqli proof which is the Hadith of Rasulullah SAW. ${ }^{24}$

For the purpose of this article, the examples of extremism set out by the respondents can be classified as follows:-

\section{i. In performing the acts of worship}

There are Muslims who are extreme in performing the acts of worship. These Muslims tend to be excessive in their acts of worship to Allāh SWT. Examples of such extreme acts are observing the fast all year and continuously performing the salät. However Islam

'asabiyyah (dogmatic) can be found in a Hadith of Rasulullah SAW. which bears the following interpretation "Not from amongst us whoever calls to "așabiyyah and not from amongst us whoever wages war for "așabiyyah and not from amongst us whosoever die as a result of "aṣabiyyah." (Narrated by Abū Dāwūd in Bāb fī al'Așabiyyah, Hadith No. 3440).

${ }^{24}$ Such as can be found in the Ahädith of Rasulullah SAW. which encourage Muslims to practise a moderate stance in performing the acts of worship to Allāh SWT. 
promotes moderation even in the acts of worship. This is illustrated in the following Hadith of Rasulullah SAW in Sahịh al-Bukhārì Book 3 Volume 31 (Fasting), Hadith No. 198 whose interpretation is as follows:-

Narrated by 'Abd Allāh bin 'Amr:

"The news of my daily fasting and praying every night throughout the night reached the Prophet. So he sent for me or I met him, and he said, "I have been informed that you fast everyday and pray every night (all the night). Fast (for some days) and give up fasting (for some days); pray and sleep, for your eyes have a right on you, and your body and your family (i.e. wife) have a right on you." I replied, "I have more power than that (fasting)." The Prophet said, "Then fast like the fasts of (the Prophet) Dāwūd". I said, "How?" He replied, "He used to fast on alternate days, and he used not to flee on meeting the enemy." I said, "From where can I get that chance?" ('Ata' said, "I do not know how the expression of fasting daily throughout the life occurred.") So, the Prophet said, twice, "Whoever fasts daily throughout his life is just as the one who does not fast at all."

Worship in Islam is wide and vast. It is not only restricted to the acts of obligatory worship but includes man's daily deeds (performed for the sake of Allah SWT, that they are rightful and according to shari'ah) throughout his life. As such a correct understanding of such a concept of worship in Islam will not give rise to al-ghuluwwun fi al-din. On the other hand, an inadequate understanding of the concept of worship may also give rise to either extreme acts of worship as mentioned above or a very liberal stance towards the acts of worship. 
Therefore the ability to understand the right concept of worship is crucial and of importance. This ensures adherence and consistency with man's role as servant and khalifah of Allāh SWT which is founded upon the sources of Islamic epistemology as mentioned in the preceding section.

\section{ii. In dealing with sociological interaction}

Respondents R5 and R9 mentioned that in managing the relationship between Muslims and non-Muslims, there are Muslims who believe in enmity towards non-Muslims and that it is justifiable to wage war against them.

In addition R1, R2, and R7 also stated that in governing the relationship among Muslims, there is also a group of Muslims who believed that if the sect or group of Muslims' interpretation is not in accordance to their interpretation of the sources of knowledge in Islam, then it is also justifiable to label this group of Muslims as "Käfir" (non-believers). This therefore provides a justified platform for these Muslim extremists to give this group of Muslims a similar treatment as the nonMuslims.

All respondents stated that according the teachings of Islam, through the understanding of the disciplines, for example, of fiqh and mu'amalah, the interaction among Muslims and the relationship between a Muslim and a non-Muslim are already outlined in detail. In fact based on Islamic epistemology and ontology Islam has given the guidelines and circumstances when a Muslim can retaliate with the non-Muslims or even among Muslims themselves. This shows a dire need for Muslims to be ensured of understanding the true and correct instructions of Islam.

\section{iii. In politics}

$\mathrm{R} 1, \mathrm{R} 2, \mathrm{R} 3, \mathrm{R} 5$ and $\mathrm{R} 9$ averred that the elements of extremism could occur among Muslims in politics. They mentioned that there is small group of Muslims who do 
not recognise any form of government and will only declare allegiance to a caliphate system. This of course has been a cause of discord among Muslims themselves as well as with the non-Muslims.

These extremists create a lot of unrest and trouble on the basis of their misguided understanding of the naqli proofs. This could be manifested through their actions based on their understanding of the term jihād. This shows that these extreme Muslims have been unable to grasp with the Islamic epistemology correctly. In other words, the correct understanding of Islamic epistemology is required from all aspects not only in interpreting the naqli $\bar{i}$ proofs from the sources but also from the way it is to be understood.

All respondents agreed to the non-usage of the term 'Islamic extremism' as often depicted with some suggesting on a more appropriate term which is in line with Islamic epistemology. These more precise and accurate terms based on Islamic epistemology provide the actual state of affairs on the term 'extremism' as understood in Islam when compared to the usage of the term 'Islamic extremism'.

Thus this provided the platform to determine from the perspectives of these selected Malaysian Muslim academia on the causes that led to the existence of extremism among Muslims.

\section{b. Factors that gave rise to extremism among Muslims}

When respondents were asked on the factors that led to the existence of extremism among Muslim, although answers given were varied in forms but upon analysis surprisingly all respondents actually cited the lack of proper Islamic religious instructions as the main factor that contributed to the existence of extremism among Muslims. There were also other factors cited as contributing to these extremists' tendencies among 
Shereeza \& Noor Shakirah, , "Views of Selected Malaysian Muslims Academia on Extremism in Islam," Afkār Vol. 19 Special Issue (2017): 147-

Muslims. A summary of the findings is presented in Table 1.3 below:-

Table 1.3 Summary of Respondents' responses on factors that gave rise to extremism among Muslims

\begin{tabular}{|c|c|c|}
\hline $\begin{array}{c}\text { Respond } \\
\text {-ent }\end{array}$ & Factors of Extremism in Islam & Remarks \\
\hline R1 & $\begin{array}{l}\text { 1) Lack of holistic Islamic knowledge as they } \\
\text { tend to take the literal meaning or definition } \\
\text { of the religious text } \\
\text { 2) Fulfilling of the "hawa nafsu" }\end{array}$ & \\
\hline $\mathrm{R} 2$ & $\begin{array}{l}\text { 1) Lack of holistic Islamic knowledge due to } \\
\text { limited access and thus limited reading } \\
\text { 2) Psychological factor }\end{array}$ & $\begin{array}{l}\text { The root cause } \\
\text { is the qalb } \\
\text { (spiritual heart) } \\
\text { that is made up } \\
\text { of two } \\
\text { elements aql } \\
\text { (the mind) and } \\
\text { hawa (the } \\
\text { desires). }\end{array}$ \\
\hline R3 & $\begin{array}{l}\text { 1) Lack of holistic Islamic knowledge } \\
\text { 2) Psychological factor }\end{array}$ & \\
\hline $\mathrm{R} 4$ & $\begin{array}{l}\text { 1) Lack of holistic Islamic knowledge as } \\
\text { Islamic education not received since young } \\
\text { 2) Psychological factor }\end{array}$ & \\
\hline R5 & $\begin{array}{l}\text { 1) Lack of holistic Islamic knowledge } \\
\text { 2) Lack of understanding on the concept of } \\
\text { figh al-awläwiyyāt }\end{array}$ & \\
\hline R6 & Lack of holistic Islamic knowledge & \\
\hline$\overline{\mathrm{R} 7}$ & $\begin{array}{l}\text { 1) Lack of holistic Islamic knowledge } \\
\text { 2) Psychological factor } \\
\text { 3) Muslim themselves are not serious in } \\
\text { tackling the issue }\end{array}$ & $\begin{array}{l}\text { Motivate } \\
\text { members with } \\
\text { ideas on the } \\
\text { sanctity of } \\
\text { jihād and } \\
\text { shāhid with }\end{array}$ \\
\hline
\end{tabular}




\begin{tabular}{|c|c|c|}
\hline & & $\begin{array}{l}\text { the promises of } \\
\text { reward. }\end{array}$ \\
\hline R8 & $\begin{array}{l}\text { Lack of holistic Islamic knowledge as this } \\
\text { group usually do not study the foundations of } \\
\text { Islam }\end{array}$ & \\
\hline R9 & $\begin{array}{l}\text { Lack of holistic Islamic knowledge and tend to } \\
\text { interpret the religious texts literally and } \\
\text { directly without looking at the required } \\
\text { contexts such as circumstance of the reason for } \\
\text { revelation with the present situation }\end{array}$ & $\begin{array}{l}\text { Historical } \\
\text { factor from the } \\
\text { time of } \\
\text { Khawārij } \\
\text { Very rigid and } \\
\text { dogmatic in } \\
\text { approach } \\
\text { where } \\
\text { everything is } \\
\text { categorized as } \\
\text { "black and } \\
\text { white" only } \\
\text { and no in } \\
\text { between. }\end{array}$ \\
\hline R10 & Lack of holistic Islamic knowledge & \\
\hline R11 & Lack of holistic Islamic knowledge & \\
\hline $\mathrm{R} 12$ & $\begin{array}{l}\text { 1) Lack of holistic Islamic knowledge } \\
\text { 2) Exist as a result of a hostile response } \\
\text { 3) Easily makes a specific view on Islam } \\
\text { (rigid) }\end{array}$ & $\begin{array}{l}\text { Islamic } \\
\text { tașawwur } \\
\text { received is } \\
\text { minimal due to } \\
\text { colonization }\end{array}$ \\
\hline
\end{tabular}

\section{i. Lack of a holistic Islamic knowledge}

All respondents agreed that the lack of knowledge pertaining to Islam holistically is the main cause of this extreme tendency among Muslims which is particularly evident, for example, in the understanding on the concept and command of jihad. R5 however also mentioned that the lack of understanding the concept of fiqh al- 
awläwiyyāt (the understanding of priorities) is the other factor that led to the rise of Muslims extremists.

All respondents cited that the reason for such a malady is because the Islamic knowledge that these Muslim extremists are in receipt of were obtained either through informal channels or from non-authoritative sources who are deviant of Islamic teachings that propagate a balanced world view. It is due to this lack of receiving a holistic Islamic knowledge that interpretations of the religious texts are interpreted radically to justify the extremists struggle. R5 mentioned that there could be this confusion of whether these extremists are struggling for Islam or that it is more of a nationalistic struggle. On this view R10 is of the opinion that most of the struggles by these Muslim extremists is more aptly described as nationalistic struggle and not for Islam.

\section{ii. Psychological factors}

$\mathrm{R} 2, \mathrm{R} 3, \mathrm{R} 4, \mathrm{R} 7$ and R12 mentioned frustration as a psychological factor that gave rise to Muslims extremists. It is a factor that cannot be negated as it is closely related with the concept of man's creation. It is innately inherent in humans to control the nafs $s^{25}$ because failure to do so will result in frustration. Frustration can lead to extreme actions. In this aspect R2 stated that the root cause of all these is the qalb (spiritual heart) which in turn has two elements hawā and 'aql. According to R2 as long as this spiritual heart is not cleansed, then the malady that befell

\footnotetext{
${ }^{25}$ According to al-Ghazali, the nafs is the place of anger and desire in humans and that the nafs is related to the spiritual heart. In referring to nafs, Muslim scholars agree that there are at least three states of nafs which is clearly mentioned in al-Qur'an the best being nafs almutma'innah (the nafs at peace), nafs al-lawwämah (the nafs that blames) and the lowest being nafs al- 'ammärah (the nafs that urges evil). Noor Shakirah Mat Akhir, Al-Ghazali and His Theory of the Soul: A Comparative Study (Penerbit Universiti Sains Malaysia, 2008), 141-144.
} 
the Muslim community will continue and that any form of solving this problem will be to no avail. Since Islamic epistemology recognizes the important role played by the heart, it is this heart that control's man's thoughts and behaviour. This is very much in line with a Hadith of Rasulullah SAW on the role of this qalb ${ }^{26}$.

These responses showed that respondents all perceived that the lack of the right to the receipt of a holistic Islamic instruction had contributed to these extreme tendencies among Muslims. However in relations to the term 'Islamic extremism' respondents replied that there were a number of factors that gave rise to the perception of extremism of Muslims by nonMuslims. Findings on this are presented in the next subsection.

\section{c. Factors that gave rise to the perception of extremism of Muslims by non-Muslims}

As a means towards ascertaining the perception of selected Malaysian Muslim academia on 'Islamic extremism', this research also sought to determine their perception on the factors that have led to the rise of extremism among Muslims which has been discussed above.

However findings have shown that the reasons attributed to extremism amongst Muslims and the factors that gave rise to extremism of Muslims by non-Muslims are entirely different based on the perception of these respondents. Table 1.4 below provides a summary of the respondents' responses on the factors that gave rise to the perception of extremism of Muslims by non-Muslims.

\footnotetext{
${ }^{26}$ As can be found in a part of the Hādith narrated by An-Nu'man bin Bashir: "Beware! There is a piece of flesh in the body if it becomes good (reformed) the whole body becomes good but if it gets spoilt the whole body gets spoilt and that is the heart." (Sahịh al-Bukhārì, Book 1, Volume 2 (Belief), Hadith No. 49).
} 
Shereeza \& Noor Shakirah, , "Views of Selected Malaysian Muslims Academia on Extremism in Islam," Afkār Vol. 19 Special Issue (2017): 147-

Table 1.4 Summary of Respondents' responses on factors that gave rise to the perception of extremism of Muslims among non-Muslims

\begin{tabular}{|c|c|c|}
\hline $\begin{array}{c}\text { Respon } \\
\text { dent }\end{array}$ & $\begin{array}{l}\text { Factors of Extremism of Muslims by non- } \\
\text { Muslims }\end{array}$ & Remarks \\
\hline R1 & $\begin{array}{l}\text { 1) Media } \\
\text { Lack of understanding on the true message of } \\
\text { Islam }\end{array}$ & \\
\hline $\mathrm{R} 2$ & $\begin{array}{l}\text { 1) Media } \\
\text { 2) Politics } \\
\text { 3) Lack of understanding on the true message of } \\
\text { Islam }\end{array}$ & $\begin{array}{l}\text { The role of } \\
\text { the qalb } \\
\text { (spiritual } \\
\text { heart) again } \\
\text { plays a role }\end{array}$ \\
\hline R3 & $\begin{array}{l}\text { 1) Media } \\
\text { 2) Politics } \\
\text { 3) Lack of understanding on the true message of } \\
\text { Islam }\end{array}$ & \\
\hline $\mathrm{R} 4$ & $\begin{array}{l}\text { 1) Media } \\
\text { 2) Lack of understanding on the true message of } \\
\text { Islam }\end{array}$ & \\
\hline R5 & $\begin{array}{l}\text { 1) Media with a large proportion due to } \\
\text { Hollywood's stereotyping Muslims in the films } \\
\text { 2) Politics } \\
\text { 3) Lack of understanding on the true message of } \\
\text { Islam and thus view Muslims as synonymous to } \\
\text { Islam }\end{array}$ & $\begin{array}{l}\text { Largely due } \\
\text { to the need to } \\
\text { maintain } \\
\text { economic } \\
\text { supremacy of } \\
\text { the West }\end{array}$ \\
\hline R6 & $\begin{array}{l}\text { 1) Media } \\
\text { 2) Lack of understanding on the true message of } \\
\text { Islam which leads to non-muslims being } \\
\text { judgmental over Muslims }\end{array}$ & $\begin{array}{l}\text { View the acts } \\
\text { of the } \\
\text { minority as } \\
\text { representing } \\
\text { the vast } \\
\text { majority }\end{array}$ \\
\hline
\end{tabular}




\begin{tabular}{|c|l|l|}
\hline R7 & $\begin{array}{l}\text { 1) Media } \\
\text { 2) Lack of understanding on the true message of } \\
\text { Islam }\end{array}$ & \\
\hline R8 & $\begin{array}{l}\text { 1) Media } \\
\text { 2) Lack of understanding on the true message of } \\
\text { Islam }\end{array}$ & \\
\hline R9 & $\begin{array}{l}\text { 1) Media } \\
\text { 2) Politics } \\
\text { 3) Lack of understanding on the true message of } \\
\text { Islam }\end{array}$ & \\
\hline R10 & $\begin{array}{l}\text { 1) Media } \\
\text { 2) Lack of understanding on the true message of } \\
\text { Islam }\end{array}$ & \\
\hline R11 & $\begin{array}{l}\text { 1) Media } \\
\text { 2) Lack of understanding on the true message of } \\
\text { Islam }\end{array}$ & \\
\hline R12 & $\begin{array}{l}\text { 1) Media } \\
\text { 2) Lack of understanding on the true message of } \\
\text { Islam }\end{array}$ & \\
\hline
\end{tabular}

\section{i. The Media}

All respondents agreed that among the main factor which had brought a negative undertone to the Muslims on this issue is largely caused by the media. The respondents stated that this is inevitable in the wake of globalization and technological advances as the media is largely controlled by the non-Muslims.

\section{ii. Politics}

According to R2, R3, R5 and R9 cited political interest as another contributing factor that gave rise to the perception of extremism by the non-Muslims. This political interest has arisen largely due to the economic interest that the non-Muslim countries have on the Muslim countries' soils such as oil and other raw materials. 
In addition, R5 mentioned that the labelling of extremism to Islam is a Western reaction towards the resurgence of Islam especially post-independence of the Muslim countries. According to R5, historically most of these Muslim nations were at one time dominated and colonized by the Western powers of the time such as Britain, France and Holland. Although these Muslim countries could be said to have attained political independence from these Western powers nonetheless these Islamic countries are not economically or culturally free from them.

In order to ensure that there is a balance of power in the world by those Western powers, thus any Muslim country that is economically independent is either attacked or is imposed economic sanction. In doing so, the balance of power can be maintained and that the vested interest in the economy of the Muslim nation is controlled by the non-Muslim nations.

\section{iii. Lack of understanding on the true message of Islam}

Another factor that can lead to the negative perception of extremism in Islam by the non-Muslims is the source of information from which they received about Islam and the message it brings. For example, this is further aggravated by a small group of Muslims whose extreme actions in justifying the killing of non-Muslims civilians as jihād. However as jih $\bar{a} d$ is the Qur'anic injunction, the actions of these small groups of Muslims have thus cast terror to these non-Muslims on Islam. Thus this has led to their inability to comprehend the true message of Islam. Due to this misunderstanding some of these non-Muslims are biased, prejudicial and judgmental towards the religion of Islam and of those who profess the religion.

\section{d. Discussions}

Based on the findings presented above, it can be surmised that from the Malaysian Muslims Academia perspective 
the concept of Islamic extremism does not exist as they unanimously disagreed even with the usage or referral of such a term. However concept permeating on extremism within Islam (or for any religion for that matter) does exist. Three patterns on deriving the concept of extremism in Islam can be construed.

The first pattern is derived from Islamic epistemology and tasawwur. To the respondents, in referring to extremism in Islam, the concept is best derived from Islamic epistemology itself. To them the Arabic terms such as al-ghuluww, al-tatarruf, tashaddid, and ta'așub are more precise and accurate terms to be used and derived the concept on extremism in Islam. They are more accurate and precise because these terms find support by being backed epistemologically which automatically fits well within tasawwur.

Besides referring to Arabic terms, the concept on extremism in Islam could also be derived from the concept based on extreme teachings or religious extremism. This falls within the second pattern. In this classification, extremism exists due to the misunderstanding of Islam by the Muslims themselves.

In the meantime the third pattern places the onus on the human aspects, that is, the Muslims themselves. In this pattern, the concept of extremism in Islam is derived from such understanding of Muslims extremism, militant Muslims, radical Muslims, religious extremists. From such an understanding the concept of extremism falls back squarely on the humans as the actor in playing out any extreme tendencies.

The rationale for such nomenclature is that the onus of using such terms in deriving the concept does not at all put the emphasis on the word Islam but rather on humans (as Muslims) or religion (in general and not specifically to Islam solely). This is more justifiable as it is acknowledged even in literatures that extremism is not a 
sole challenge facing Islam. In fact there are extremism tendencies in all religions.

These three patterns in which the concept of extremism in Islam is derivable nonetheless converge in its characteristics. As a summation of the above examination that notwithstanding there are three poles of views on the concept of extremism in Islam, the most conspicuous characteristic is that the extremists are small in group and a minority in the community. Another characteristic is the existence of extreme elements pervading within the Muslim community. These extreme elements are found in three main aspects - acts of worship, sociological interactions and politics.

These characteristics found within the general concept of extremism in Islam bears the following implications to contemporary $d a^{6} w a h$ in its approach to address extremism within the Muslim society. The findings suggest that in tackling extremism those who are directly involved in contemporary $d a^{6} w a h$ need to be proactive in engaging the Muslim society in these four aspects:

i. The spiritual aspects relating to the spheres of worship;

ii. Managing dimensional relationships referring to man's relationship as a servant and khalifah of Allah (habl min Allāh) and man's relationship with one another and with the natural resources (habl min al-nās) whether the interactions is in the sphere of economics, social sciences, technology and even politics.

iii. Acknowledge the importance of the media and get the media to play its role in disseminating a true and proper depiction of what Islam is and stands for; and

iv. Providing and ensuring a holistically true understanding of the primary sources of Islam (Islamic epistemology) instead of allowing a 
sectarian and eclecticism methodology of preferring one verse at the expense of the other. It refers to taking a narrow interpretation of the verses by sticking to only one type of source (i.e devoid of triangulation methodology) instead of from other sources as well.

\section{Suggestions on How to Counter This Malady}

In order to seriously tackle this issue, the respondents have provided some suggestions on how to counter the permeation of extremism within the Muslim society. From the respondents' suggestions, four main approaches of contemporary $d a^{6}$ wah have been identified that could be used to overcome the challenge on extremism in Islam.

The first approach is the need to make the masjid as the centre for contemporary $d a^{6} w a h$. According to R2, the masjid needs to be used more as the centre for knowledge whilst R4 said to intensify efforts on how Islam should be practiced ought to be the focus. Although R4 did not make mention of the masjid nonetheless the masjid could be used as the platform for engagement in intensifying efforts in addressing the practical aspects of practising Islam.

The second approach in contemporary $d a^{6} w a h$ is through the development strategy approaches. R6 mentioned about the need to use both the tops-down and bottoms-up approaches to tackle the issue. For the Islamic nations, this calls for the empowerment and a proactive stance by the Organization of the Islamic Conference (or OIC) ${ }^{27}$ as suggested by R9. For a non-

27 The Organization of the Islamic Conference (OIC) is the second largest inter-governmental organization after the United Nations which has membership of 57 states spread over four continents. The Organization is the collective voice of the Muslim world and ensuring to safeguard and protect the interests of the Muslim world in the spirit of promoting international peace and harmony among 
Islamic state this means governmental leaders inevitably must have the proper understanding of "Islam" as opposed to "Muslim" whilst the Muslim society should strive to constantly build close rapport with the governmental leaders. In this regard R5 stated that the non-Muslims must be able to differentiate between "Islam" and "Muslim". R7 talked about the efforts of individual Muslims and Islamic non-governmental organizations (NGOs) to provide a forum akin to those done by the Muslim Debate Initiative ${ }^{28}$.

The third approach is through the academic route. R7 further mentioned that there is a dire need to address the issues on extremism in Islam academically as the issues on the interpretation of the religious texts span two extreme ends of approaches - one that is too dogmatic and at the other end one that is too liberal.

The fourth approach, which is unanimously suggested by all respondents, is the need to ensure the

various people of the world. "About OIC" accessed December, 5 2010, http:www.oic-oci.org/page_detail.asp?p_id=52.

${ }^{28}$ The Muslim Debate Initiative (or MDI), is a grassroots-to-high level research, formed by experienced Muslim debaters, apologists, political analysts, researchers and speakers from all sections of the Muslim community. MDI aims at promoting debate, dialogue, discourse and discussion between all sections of the global community. Muslim Debate Initiative and the Debate Initiative, "Main," accessed July 24, 2010, http://www.thedebateinitiative.com/\#.

In the Malaysian context, the Prime Minister Datuk Seri Najib Tun Razak had touched on the need to "re-isolate" the extremists. Among the points he averred at the International Forum on the Creation of Global Citizen: Media Liberalisation And the New Political Realities in October 2010 in conjunction with the $61^{\text {st }}$ Umno General Assembly at the Putra World Trade Centre the Prime Minister had called upon the media to help in the global fight against extremism ("PM Enlists Media in Global Fight Against Extremism," The Star, October 20, 2010, accessed December 6, 2010 ,

http://thestar.com.my/news/story.asp?file=/2010/10/20/nation/7257 $030 \& \sec =$ nation). 
receipt and acquisition of knowledge on Islam from the right sources. Principally all respondents suggested that it is incumbent upon all Muslims to receive and acquire Islamic knowledge from the right sources to ensure the right understanding on Islam which abides by the various Islamic disciplines is obtained. As an example in learning the tafsir there is a need to have the background of Arabic language among other aspects to ensure that a correct understanding of the religious texts of Islam could be achieved.

On this note R12 stated that the opportunity for a holistic Islamic education must be given to the Muslims. R2 and R9, however, are of the opinion that the problem of extremism in religion which permeate the Muslims is impossible to eliminate completely. Nonetheless efforts to minimize its existence and proliferation must still be undertaken. Another suggestion brought forward is the ability to comprehend the sources of knowledge in Islam. This means that there is a pressing need to be imbued with the background of the various disciplines of knowledge in Islam such as tafsir, the Arabic language and fiqh, etc.

The suggestions on these four approaches in contemporary $d a^{6}$ wah bear positive implications to the challenge of extremism in Islam. Based on the views of the respondents, except for R1, R2, R11 and R12, the successful implementation of contemporary $d a^{6}$ wah requires that three pre-conditions must be met. First, all Muslims need to unite by refraining from using the term 'Islamic extremism' or 'Muslims extremists' in their writings or speeches. Second, these terms should be obliterated from the vocabulary of the Muslims and the term extremism should not co-exist with the word "Islamic" at all. Third, there is a need for a consensus among all Muslims to avoid at all costs the usage of any term that is used to describe the extreme actions of a certain group of Muslims. 
This is because the term alluded to could still be used yet again by non-Muslims with the bias meaning when referring to Muslims. There is a need for the Muslim society to correct the situation by refraining from the term itself.

Interestingly, respondents agree that in terms of contemporary $d a^{6}$ wah the onus is on them as Muslims intellectuals and academicians who must put in the efforts representing the Muslim society specifically to counter back the irresponsible usage of the term by any party to describe the Muslim society. This is in tandem with the views expressed by Ozay Mehmet. ${ }^{29}$ According to R6 and R7, in doing so, the non-Muslims should be given the correct understanding of Islam which is based on the Islamic tașawwur and epistemology by the Muslims themselves who adhere to the concept of wasata (correct and balanced).

\section{Conclusion}

The article has set out that information collected showed that that there exist two inclinations to the perception of 'extremism' among the selected Malaysian Muslim. When analysed based on the fundamentals to the development of human thoughts from the Islamic perspective, findings show that the majority of respondents did not agree to the usage of the term from the literal or technical sense whereas the minority of respondents although agreed to the usage of the term do not agree to its technical nuance that equates the term to any aggressive and terrifying actions done by the Muslims. It provides a reliable basis and justification to denounce and reject outright the use of the term 'Islamic extremism'.

In addition, this article has highlighted the differences in the understanding of the term 'extremism'

\footnotetext{
${ }^{29}$ Ozay Mehmet, “Writing about Islam”, 58-76
} 
as used by another party to conjure the situation of the Muslim society permeating within the Muslims themselves. It compels those who would like to bring an end to extremism amongst Muslims to work closely with Muslims who have the correct and balanced view on Islam as guided by the religious texts which are firmly grounded on Islamic epistemology, tașawwur and ontology.

This means, any means by non-Muslim society to seriously yet inoffensively undertake to find a solution towards extremism in Islam requires and understanding of the religious texts based on Islamic epistemology, tașawwur and ontology as well. This therefore suggests that the challenge to the call of Islam for Muslims today is a dire need to use the wisdom by the choice of the most precise term yet simultaneously enlightening the nonMuslims on Islam's true stance.

\section{References}

Abū Dāwūd, Sulaymān ibn al-Ash`ath al-Sijistānì. Sunan $A b \bar{i} D \bar{a} w \bar{u} d$. Bayrut: Dar al-Kitāb al- 'Arabì, 1970.

Ahmad Redzuwan Mohd Yunus. Sejarah Dakwah. Kuala Lumpur: Pustaka Nasional, 2001.

Alrassi, Abdulrahman. "Fighting against Religious Extremism and Islamophobia: The Pillar for a Sustainable Harmony between West and Islam." In SEA: Practical Application of Science, vol. 2 issue 1(3)/ 2014: 39-47.

Amini Amir bin Abdullah. "Pemikiran Islam Peranan Tokoh-tokoh Islah dan Cabaran Aliran-aliran Pemikiran Semasa" (Master Thesis, Universiti Sains Malaysia, 1994).

Az-Zubaidi, Zain-ud-Din Ahmad bin Abdul- Lateef. The Translation of the Meanings of Summarized Sahih AlBukhari Arabic-English. Translated by Muhammad Muhsin Khan. Riyadh: Maktaba Dar-us-Salam, 1994. 
Barlas, Asma. "Jihad, Holy War, and Terrorism: The Politics of Conflation and Denial.'In The American Journal of Islamic Social Sciences, 20(1): 46-62.

Chua, Yan P. Kaedah dan Statistik Penyelidikan: Kaedah Penyelidikan Buku 1. Malaysia: McGraw-Hill (Malaysia) Sdn. Bhd., 2006.

Denzin, Norman K. and Lincoln, Yvonna S. Handbook of Qualitative Research. Thousand Oaks: Sage Publications Inc., 1994.

H. Mahmud Yunus. Kamus Arab-Indonesia. Jakarta: Yayasan Penyelenggara Penterjemah/Pentafsiran AlQuran, 1972.

Al-Haddadi, Ali ibn Yahya. "The Forbiddance and Danger of Extremism." Translated by Abu Az-Zubayr Harrison. Accessed July 30, 2010.

Haron Din et.al. Manusia dan Islam: Jilid 3. Kuala Lumpur: Dewan Bahasa dan Pustaka, 1993.

I. Doi, Abdul Rahman. Shari 'ah: The Islamic Law. Kuala Lumpur: A.S. Noordeen, 1984.

Kamali, Mohammad Hashim. "Extremism, Terrorism and Islam: Historical and Contemporary Perspectives." In Islam \& Civilisational Renewal, 6(2), 148-165.

Mehmet, Ozay. "Writing about Islam: The Role of Academics." In Humanomics, 10(2), 58-76. Retrieved from http://dx.doi.org/10.1108/eb018750 on 10 December, 2016.

Mohd. Majid Konting. Kaedah Penyelidikan Pendidikan. Kuala Lumpur: Dewan Bahasa dan Pustaka, 1998.

Mohd. Sulaiman Haji Yasin. Pengantar Aqidah. Kuala Lumpur: Dewan Bahasa dan Pustaka, 1984.

Muhammad Syukri Salleh. 7 Prinsip Pembangunan Berteraskan Islam. Kuala Lumpur: Zebra Editions Sdn. Bhd. and Pulau Pinang: Projek Pengurusan Pembangunan Islam, Pusat Pengajian Sains Kemasyarakatan, Universiti Sains Malaysia, 2003. 
Muslim Debate Initiative and the Debate Initiative, "Main." Accessed July 24, 2010. http://www.thedebateinitiative.com/\#.

Noor Shakirah Mat Akhir and Shereeza Mohamed Saniff. "Intellect and Human Being in Islamic Intellectual Tradition." (Paper presented at the $14^{\text {th }}$ International Conference on Thinking, Kuala Lumpur Convention Centre, Kuala Lumpur, June 22-26, 2009).

Noor Shakirah Mat Akhir. Al-Ghazali and His Theory of the Soul: A Comparative Study. Pulau Pinang: Penerbit Universiti Sains Malaysia, 2008.

Organization to the Islamic Conference (OIC), "About OIC." Accessed December 5, 2010. http://www.oicoci.org/page_detail.asp?p_id=52.

Quran Explorer Inc. "Bukhari Muslim Malik Dawud Hadith Collection." Retrieved from http://quranexplorer.com/. Accessed July 24, 2010.

Rohana Yusof. Penyelidikan Sains Sosial. Pahang: PTS Publications \& Distributors, 2003.

Ruhanas Harun. "On Youth and Terror." Accessed December 22 , 2009. http://www.ssig.gov.my/ssig/kcent/material/PAPER_C ONFERENCE_ON_YOUTH_ AND_TERROR$\% 20$ ruhanas.pdf.

Sanjeev, Kumar H. M. "Responding to Western Critiques of the Muslim World: Deconstructing the Cliché of Islamophobia and the Genealogies of Islamic Extremism." In British Journal of Middle Eastern Studies, 579-598. Retrieved from 10.1080/13530194.2015.1037247 on 10 December, 2016.

Yin, Robert K. Case Study, Research Design and Methods. London: Sage Publications, 1984.

Zain al-Abdin, Al-Tayib. "The Intellectual Roots of Terrorism." University of Khartoum. http://www.ssig.gov.my/wp- 
Shereeza \& Noor Shakirah, , "Views of Selected Malaysian Muslims Academia on Extremism in Islam," Afkār Vol. 19 Special Issue (2017): 147194

content/uploads/2013/07/The-Intellectual-Roots-ofTerrorism-altayib.pdf. Accessed December 22, 2009. 
Shereeza \& Noor Shakirah, , "Views of Selected Malaysian Muslims Academia on Extremism in Islam," Afkār Vol. 19 Special Issue (2017): 147194 